\title{
AN OPEN-AIR SELF-MANAGED SOCIAL CENTER CALLED OCCUPY
}

\author{
SOPHIE TOUPIN
}

Five College Women's Studies Research Center

\begin{abstract}
I propose the concept of squatting as a way of exploring and understanding the recent Occupy movement and other manifestations that have taken hold of a physical and virtual space. To do this, I focus on squatting as a protest tactic employed by social movements, to gather, create and transform private and public spaces in common spaces. I follow Miguel Martinez (2006) premise that squatting has been aimed at constructing liberating spaces for living, communicating, and criticizing the global city and confronting capitalism. Using such framework to analyse the Occupy movement helps bring to the forefront what appears to be a somewhat similar experience, this time however, not solely via the occupation of buildings, but also via the occupation of parks or squares. The act of reclaiming and decommodifying open 'public' spaces in an attempt to create autonomous experiments visible to and 'experimentable' by all seem to have brought much visibility, appeal and relative openness to and of the occupy movement. From there, I discuss the particularities with moments of squatting, particularly with the occupied social centers movement, and instances of occupy sites in North America to underline a number of hidden and visible characteristics and features these phenomena share. In North America, the concept of squatting, including the practice of occupied social centers, seems to have had much less prevalence and impact on social movements than in Europe, but the occupy movement seems to have opened up new repertoire of actions for both activist and non-activists a like.
\end{abstract}

\section{Keywords}

Occupy Wall Street, collective action frames, self-managed social centers, squatting, autonomous spaces

\section{Corresponding author:}

Sophie Toupin, Email: sophie.toupin@mcgill.ca.

The author wishes to acknowledge the support of the Five College Women's Studies Research Center in South Hadley, Massachusetts, USA. The author was a research associates at the Center in 2012-2013, during which time the bulk of the research and writing for this paper was completed. The author would also like to thank all those who took the time to spoke with me during the data collection, and the editor, the associate editor and the two anonymous reviewers for their comments on the articles. 
T The surge of protest that has swept many countries in the world in recent years seems to have signalled a change in citizen repertoire of actions and contentious politics. In the United States of America (USA), this burst in social movement actions was manifested by the 'occupation' of parks and squares that began with Occupy Wall Street (OWS) on September 17, 2011 and quickly spread viral to more than 951 cities in 82 countries in a matter of weeks. A few months after the start of the encampments, the parks and squares were evicted in what has been recognised by activists as a national coordinated effort to evict the occupied spaces. As a result of the evictions, some occupy sites decided to attempt to take over empty buildings, other parks or join the Occupy Our Homes campaign, an offshoot of the Occupy movement aimed at stopping foreclosures or allowing foreclosed houses to be occupied. At a time where more than 4 million Americans have lost their homes to foreclosures and/or experimented devastation in the wake of Hurricane Sandy, the right to housing has become central to many occupiers, post-eviction. The issue of the right to housing is not new in the USA, but seems to have gone a step further since Occupy. Thanks to the legacy of the Occupy movement, some local groups went as far as using direct actions to reclaim emptied houses through common repossession (Burns, 2012).

Since the American Autumn began, much writing and analysis has been done and continues to be done on the Occupy movement, but few have looked at the connections between Occupy and the practice of squatting. Drawing parallels between Occupy and squatting, including self-managed social centers, allows for new forms of exploration and interpretation of the Occupy movement and its offshoots, and help shed light on new trajectories local groups have taken to make the right to housing a reality. It also helps to better understand a protest tactic that has gained momentum and traction with social movement, including the M15M (May 15 Movement), the Syntagma square movement in Greece, Tahrir square and the Occupy movement, among others. Moreover, it highlights convergence between social movements and points to what Martinez and Garcia (2001) call the "cumulative chains of activist exchanges" (p. 3).

Squatting in an urban setting has been defined as "living in - or using otherwise - a dwelling without the consent of its owner" (Pruijt, 2011, p. 1). According to this definition, squatters take buildings with the intention of relatively long-term use. In this context, squatting can be referred to as a tactic to improve the living situation of an individual or it can refer to an action repertoire used by social movements. Squatting can also be understood as an urban movement where citizens attempt to (re)appropriate their urban environment and challenge the mantra of the protection of property rights (Martinez, 2012; Pruijt, 2007).

The practice of self-managed occupied social centers is different from squatting for housing in so far as it provides a space for organising political, social and cultural events. In other words, it provides a space for people from a community to organise events such as concerts, or "political" discussions, and have bike repair and/or sleeping facilities. Social centers can be defined as self-managed autonomous spaces that are either squatted or that have been rendered legal by local authorities. Mudu (2004) argues that social centers use squatting as one of their essential component "not only because it involves breaking the law, but because it is a way of obtaining what has been denied" in terms of space in neo-liberal cities (p. 923). Social centers have their roots in the Italian autonomia movement and German autonome movements (Katsiaficas, 2006; Mudu, 2004; Pusey, 2010) and have spread rapidly in Europe in the past few decades. 
In North America, self-managed social centers are a foreign practice and therefore few exist. Nonetheless, the recognition of the need for the creation of autonomous spaces in North American cities has gained traction, particularly with the Occupy movement.

The issue of space was at the core of the Occupy movement. By occupying symbolic parts of cities, often in financial districts, the Occupy movement tried to disrupt business as usual. It was also a way to challenge the privatisation of cities, by pointing to the lack of un-privatised space while reinvigorating the 'right to the city' debates (Harvey, 2008; 2012). In the past decades, occupation as a protest tactic has been widely used by social movements, whether it be through the occupation of a building, university, or factory. Throughout the ages, student's movements have occupied university buildings to protest against the corporatization of universities, among others. Factories have been recuperated by their employees as in the famous case of Argentina in the first decade of the twenty-first century following a severe economic crisis. And more recently parks and squares have been occupied by civil society in a way to resist strict austerity measures or in an attempt to resist and bring down authoritarian regimes. This has brought to the fore the call to squat private and public spaces in cities as a protest tactic, but also as a way to reclaim common spaces. It is through this wide frame of the occupation or squatting of symbolic spaces that the Occupy movement will be understood.

This paper first looks at the importance of autonomous or (re)appropriated spaces in today's resistance highlighting some of the consequences neoliberal policies have had on USA society. Then, I will discuss and analyse the ways in which OWS has succeeded in broadening up the repertoire of actions, making radical ideas such as squatting and direct actions somewhat palatable to a wide American audience in a context of "casino capitalism" (Strange, 1997).

\section{Methodology}

The methodology is based on a case study of OWS that was started on September 17, 2011 and ran until December 2012. Two qualitative methods were employed for conducting this research. First, participative observations were used to understand the rationale of the actors involved and attempt to interpret the relationship and heritage between squatting, as broadly understood, and the Occupy movement. Second, 17 indepth semi-structured interviews lasting from one to two hours in length were conducted with participants from the Occupy Movement, and then transcribed.

As a researcher invested in social movements, including the Global Justice Movement, the Occupy movement, and the 2012 Quebec Student Strike, I am sensitive to questions of researcher positionality. In relation to the interviewees, I was in part an insider, as an Occupy participant and activist, and in part an outsider as being differently aligned with other occupiers along the dimensions of nationality, gender, class, etc. During the interviews, I did not hide my activist commitment, but nor did I presume those commonalities would prevent dynamics of power and differences to emerge. I therefore acknowledge that the account presented in this paper is informed by my own positionality and contributes to "partial truth" (Clifford, 1986) to a larger body of critical ethnographic work on Occupy. 


\section{The Importance of Autonomous Spaces in Today's Resistance}

With the rise of neoliberal globalisation from the late 1970 onwards, autonomous spaces in cities have become scarce (Harvey, 2008). Universities which use to represent spaces of relative autonomy have rapidly become neoliberal enclosures (Chatterton, Hodkinson \& Pickerill, 2010), community and artist centers have been threatened by funding cuts or auctioned off to profit driven developers, parks and other outside spaces have become highly surveyed, regulated and even privatised, among others, leaving very few spaces for dialogue, meetings, resistance and radical education (McKenzie, 2010, p. 15). The corporatization of spaces in cities has also increased the process of gentrification where spaces free from corporate symbols have become a rarity (Chatterton, 2006; Harvey, 2001). This rarefication of public spaces or what Hardt and Negri (2009) call common spaces coupled with the alienation experienced with "casino capitalism" and its corollaries (foreclosures, mounting $\operatorname{debt}(\mathrm{s})$, banks bailouts and the failures of representative democracy) has reduced the possibility of moments of togetherness to organise, discuss and be exposed to other thoughts. In fact, the decline of traditional 'political' spaces where people could encounter radical alternative in their communities, workplaces and schools have largely faded away with the fierce implementation of a neoliberal paradigm. In that context, the strategy and tactic to build and foster resistance via the creation of self-managed autonomous spaces grounded in communities seem to have been adopted to react to the devastating effect of capitalism. At such a time, autonomous spaces are more and more relevant not only to counter the logic of capital, but also and especially, in an attempt to create new possibilities.

Autonomous spaces have emerged under different forms and shapes in the past decades. They have ranged from temporary autonomous villages or what Hakim Bay (1991) calls TAZ (Temporary Autonomous Zones) set up during protests to the squatting of buildings, to the creation of self-managed social centers, Independent Media Centers (IMC) or hacklabs (Maxigas, 2012) to the new wave that has taken shape in the form of the Occupy movement. Behind all these attempts at creating autonomous moments and projects is a desire to counter the dire consequences of the economic crisis, create an alternative and overall reclaim back what has been considered stolen from the people (Member of the New Yorkers Against Budget Cuts, personal communication, October 15, 2012). All and all, it seems to underline a desire to foreground radically different principles grounded in mutual aid in a time of casino capitalism.

Pickerill and Chatterton (2006) informed by the Zapatismo movement, define what they call "autonomous geographies" as those spaces where there is a questioning of the laws and the social norms of society and a creative desire to constitute non-capitalist, collective forms of politics, identity and citizenship. This definition helps to shed light on autonomous spaces, including the Occupy movement, where the intention seems to be to develop autonomous politics and a resistance toward capitalist enclosures, the alienation of everyday life and the catastrophe caused by the economic crisis (Hodkinson \& Chatterton, 2006). In the past decades, social centers and political squats (See Pruijt, 2013 for a discussion on the five basic configurations of squatting) have been examples of venues that have been used, mostly by activists, in an attempt to create spaces and networks of resistance that have helped shape autonomous politics. The creation of such spaces has also helped with movements' convergence that is bringing a variety of movements and groups to collaborate with one another (Martinez \& Garcia, 2011). 


\section{A New Frame of Contestation}

Occupy Wall Street (OWS) aimed at denouncing the economic crisis, the foreclosures, the mounting debt(s), the bank bailouts and among others, the failures of the American representative democracy. It was a response to unbridled and crony capitalism for some and the failures of the capitalist system for others. OWS was also an effort to join forces and enlarge a movement of contestation that had already taken off in North Africa, in some European countries and also in the US state of Wisconsin (Walkerville tent city).

All these networks of outrage and hope, as Castells (2012) dubs them, happening in different parts of the world seemed to be a demonstration of the wide adoption of a collective action frame that included the use of the "occupation" or squatting of space as a protest tactic. Even though, this protest tactic seemed to dominate Occupy's main mode of actions, other powerful methods were used in conjunction, such as consciousness raising and education through practice. Benford and Snow (2000, p. 614) define collective action frames as an action-oriented set of beliefs and meaning that inspire and legitimate the activities of social movements.

When analysing the M15 (May 15, 2011) movement, Fuster Morell (2012) argues that the movement helped shift the terms of opposition from a thematic movement (feminist or environmental movement), to a more general meta-political frame of contestation. This analysis can be extend to the Occupy movement as activists have aimed to move away from single-issue organising to connecting the dots between different forms of oppressions (Member of the People of Color (PoC) caucus, personal communication, October 24, 2012). Activists framed their discourse in such a way that capitalism, patriarchy, austerity measures, sexism, racism, among others, were all seen as interdependent and mutually reinforcing. This new collective frame of contestation cut across and connected the new waves of social movements that sprung up in the past two years helping movements to converge and exchange practices.

This is reminiscent of earlier social movements such as the Global Justice Movement of the $2000 \mathrm{~s}$, which opposed corporate globalisation by organising festive protests in the streets of cities during variety summits. The Global Justice Movement is an important reference point to understand the ways in which OWS and its offshoots have succeeded in having such a wide appeal (Pleyers, 2010).

Despite some of the criticisms that contested the collective frame of unity in diversity (See Campbell, 2011; Juris, Ronayne, Shokooh-Valle, \& Wengronowitz, 2012) the slogan We are the $99 \%$ is one that has largely embodied the new meta political frame of contestation. Moreover, this frame has been able to link both local concerns and global ones showing that the ways in which the system works has negative consequences on the large majority. Thanks to this framing and the occupation of space as a protest tactic, OWS ended up resonating deeply in the American consciousness and beyond.

The attempt to embody and materialise this new meta-political frame of contestation using the protest tactic started in the USA with a variety of actions prior to September 17, 2011. In June, the Bloombergville encampment was set up in front of the New York mayors' office to oppose the cities budget cuts (Member of the New Yorkers Against Budget Cuts, personal communication, October 15, 2012). At the same time, a group in Washington DC prepared an action set for October 6 to seize DC Freedom Plaza in the spirit of non-violent resistance similar to the Arab Spring and the Midwest awakening (Walkerville Occupation). A reinforcing momentum for occupying spaces was engendered 
by the online call made in July 2011 by the Vancouver-based culture-jamming magazine, Adbusters. At that time, Adbuster had asked for 20,000 people to "flood into lower Manhattan, set up tents, kitchens, peaceful barricades and Occupy Wall Street for a few months" (Adbusters, 2011). Adbusters' on-line call used the framework of the one demand and even proposed a presidential commission to remove money out of politics as an idea for the movement to take forward. The Adbusters' call, with its one demand, did not exactly fit into the meta-political frame of contestation that was gaining traction among activist in the USA.

The call was rather using somewhat of the old single-issue framework: removing money out of politics. Nonetheless, the main protest tactic was different than the one used by the Global Justice Movement (GJM). During the GJM, activists organised around particular meetings whether it be the G8, G20, North Atlantic Treaty Organization (NATO) and World Trade Organisation (WTO), among others in an attempt to disrupt it and bring attention to the negative consequences brought out by the decision of big institutions and corporations. The tactic of 'occupation' of parks and squares or encampments used by the Occupy movement was largely new in the USA and helped capture the zeitgeist of its time.

On August 2, 2011, the first People's Assembly was organised in Wall Street and largely rejected the one demand framework proposed by Adbusters. For OWS, demands addressed to the ones in power, the politicians, only legitimatised the system that was according to them corrupted and that had failed the people in favouring interest groups and big corporations (Member of the Media Team, personal communication, November 5,2012 ). Instead of making demands they used the method of direct action to reclaim space and attempted to create pre-figurative politics.

\section{The Tactic of Occupation that Triggered the Occupy Movement}

From its inception, Occupy Wall Street (OWS) used direct action tactics to create a self-managed autonomous space. The first of such action repertoire was to take over Zuccotti Park. The action to take over a park was extremely organised and planned, as it is the case for taking over an empty building, which ought to be discrete and secreted. On September 17, 2011, thirty minutes before 3 p.m., the time set for occupying a park, the Tactical Committee of Occupy Wall Street (OWS), who had been given the task by the General Assembly (GA) to scout possible locations to occupy, released a map of eight possible locations. Location number two, known as Zuccotti Park, was identified as the one to be targeted for the occupation. The Tactical Committee composed of only three people, distributed flyers and asked the hundred of people present at the General Assembly happening down in Wall Street, to proceed to the identified location and start occupying the Park (Member of the media team, personal communication, November 9, 2012).

Secrecy with releasing the information on the location was used to ensure maximum success rate with the occupation of the space. A conscious decision was also made not to use any kind of advanced technology such as Facebook, Twitter and the like, to make the possibility of police interception as minimal as possible. On September 17, 2011, the police was unprepared and unable to prevent the occupation of Zuccotti Park.

On the night of September 17, more than one thousand people gathered for the first General Assembly in the occupied (in opposition to vacant) park. Wall Street would have, 
until OWS eviction on November 15, a new fixture on its landscape reminding them of the opposition to a financial system that was favouring a minority and plaguing a majority. This was the start of an experiment where direct democracy, horizontalism, mutual aid and self-management would prevail. Additionally, thanks in part to the power of the Internet (social networking sites and livestreaming in particular) Occupy sites, mushroomed all over North America, Europe and beyond in a matter of weeks (Castells, 2012). Such an experiment in parks and squares and at such a scale was unprecedented in the United States.

\section{The Open-air Self-Managed Occupied Social Center called Occupy}

OWS transformed a Privately Owned Public Space (POPS) known as Zuccotti Park (also known as Liberty Square) into an open and inviting space for its participants and the interested public. POPS have been a common feature in NYC where they have sprung up in the $1960 \mathrm{~s}$ as a way to provide incentive to developers to donate a certain amount of their property for public space in exchange for flexibility in their main structure's height, among others (McKenzie, 2011).

Occupy created a life of its own which was, some activists would argue, an attempt to be a post/despite capitalist endeavour (Member of the Trans World Order Affinity Group, personal communication, November 21, 2012). Direct democracy via general assemblies (GA) happened everyday to discuss issues related to Occupy, a kitchen served food almost 24 hours a day, there were sleeping arrangements, a library was set up so that people could flirt with books and magazines rarely available otherwise, there was a media center with wireless access to the Internet, OWS created its own news, its own newspaper called the Occupied Wall Street Journal, etc. To do this, to have the park function somewhat as an autonomous entity, OWS relied on collective actions via the creation of working/affinity groups, caucuses and committees responsible for a multitude of activities, and who were accountable to the wider general assembly.

In the first weeks of OWS, activists and citizen marvelled at what OWS was attempting to create and the principles it foregrounded: solidarity, mutual aid, horizontalism, and direct democracy, among others. In fact, this act of reclaiming and decommodifying an open, privately owned public space was an attempt to create an autonomous experiment visible to and 'experimentable' by all, which generated a lot of enthusiasm among Americans and a lot of support from similar movements. The resonance of hope and transnational solidarity can be illustrated in a message sent by Egyptians to the Occupy movement on October 24th, 2011:

To all those in the United States currently occupying parks, squares and other spaces, your comrades in Cairo are watching you in solidarity [...] So we stand with you not just in your attempts to bring down the old but to experiment with the new. [...] We are reclaiming those same spaces of public practice that have been commodified, privatised and locked into the hands of faceless bureaucracy, real estate portfolios and police protection. Hold on to these spaces, nurture them and let the boundaries of your occupations grow (Comrades from Cairo, 2011).

One can draw parallels between self-managed social centers and the occupy sites. Social centers can be broadly described as volunteer-run, self-managed, autonomous 
spaces where people can come together to create, conspire and communicate a collective challenge against capitalism (Pusey \& Chatterton, 2008). Indeed, the occupied spaces were very close to the ethos of self-managed social centers as they were centered on the creation of alternative and parallel economic models to capitalism where horizontality, shared labour, informality and consensus can flourish. Discussing some of the characteristics of social centers, Mudu (2004) echoed what occupy sites have become in having contributed to the freedom of making rules collectively and non-hierarchically.

As a result of the Occupy movement, what we have seen emerged in force is an interest and involvement in autonomous politics and the collective use and "control" of space as part of a broader collective frame of contestation to the enclosure and alienation of everyday life experimented very acutely in the USA following the economic crisis. Like in Italy, where the disenfranchised youth in the 70s started a process of (re)claiming the city through widespread squatting of public spaces and empty buildings (Montagna, 2006; Mudu, 2004), which later would lead to the creation of self-managed social centers, activists and some members of the wider public in the USA followed a somewhat similar trajectory with the Occupy movement and its offshoots. Many of them, particularly the generation under thirty-five, had followed the accepted trajectory that going to school and getting a good education would result in getting a job. But the result was largely that those who went to university were left without a job and with massive debts, a debt (student debt) that even with bankruptcy they could not get rid of.

Occupy, as somewhat of an open-air self-managed social center, was a key organising tool in terms of political development of participants and a place of self and free-education, especially in terms of local issues and its relationship to global concerns. Speaking about the influence of the squatting movement in Barcelona on the politicization of activists in mid-2000, Jeffrey Juris (2008, p. 83) highlights the need for social movements to have open spaces where people can attend and/or give talks, socialize in alternative ways, as to create new systems of values and for sustaining a movement.

Such as self-managed social centers, Occupy sites ensured somewhat of a steadiness compared to the nomadic counter-summit events, protests or other shortlived transient spaces that had been experienced with the Global Justice Movement in the USA. Though representing another protest tactic, the Occupy movement provided, such as self-managed social centers often do, somewhat of a time frame and a known space to organise, educate and create ties not only for activists, but for a wider public. Building on the networks created before the eviction, the Occupy movement has continued its activities at different scales. The 2012 May 1st action, the September 17, 2012 (S17) 3-day of actions to celebrate the first anniversary of OWS, the Rolling Jubilee, Occupy Sandy, Strike Debt, are all examples of the continuity and vibrancy of the movement post-eviction.

The Occupy sites were also spaces that attempted to act directly against the commodifying logic of capitalism and the process of enclosures. When such spaces are experienced they can often lead to the radicalisation of a multitude of actors that would have otherwise not been exposed to new thoughts, ways of being and ways of governing (Chatterton, 2006). Moreover, the collaboration between different social movements that followed the creation of the open air autonomous space fostered what Martinez and Garcia (2011) call the cumulative chains of activist exchanges. In the case of the M15M, the resemblance between the social centers projects and the occupied camps helped spark collaboration between movements that would have not necessarily collaborated 
otherwise. The convergence between movements was facilitated by the protest tactic used and the overall project behind the occupy camps. In the case of Spain, Martinez and Garcia (2011) argue that the squatters discovered a new form of open-air occupy social center that was more accepted by the general public than marginal squats.

Occupy was also about building caring communities, which in a time of unbridled capitalism is in itself an act of countering the logic of the commodification of everything. Isabelle Dyck (2005) argues that the act of caring for the other, for their space, for their pre-figurative politics is what unite and help sustain movements. Creating spaces where solidarity can flourish among the multitude is a radical and feminist idea that helps confronts the logic of capital.

This focus on caring for communities has been particularly notable in the second year of the Occupy movement where, in many cases, Occupy facilitated a process of emancipation and empowerment for communities. This has been particularly true and visible with Occupy Sandy (OS). OS advanced a peoples' recovery against disaster capitalism and made clear that the agency for meeting needs and achieving a just rebuilding rests with the community. This can be illustrated by the words of one Occupy Sandy volunteer: "Occupy was ready to react to a natural disaster as it had reacted to an economic disaster i.e. through solidarity and mutual aid" (Member of the Media Team, personal communication, November 7th, 2012). Occupy Sandy has even been seen as outperforming the USA Federal Emergency Management Agency (FEMA), and nongovernmental organisations such as the Red Cross (Goldstein, 2012).

The emotional connectedness that has been experienced and built over time in the Occupy sites and its offshoots has also been key features of autonomous spaces. Jeffrey Juris (2008, p.97) argues that gathering in physical spaces provide forums for generating personal ties and trust. This hidden and invisible work that happens while discussing, planning an action, protecting the encampment from eviction, or while doing any kind of work that is to the larger benefit of the collective is essential in forging a sense of belonging and is feminist in nature (Chatterton, 2006). The Occupy spaces have attempted to counter the capitalist ways of entering into relations with one another by, for instance, giving free food almost 24 -hours a day.

When speaking about self-managed social centers in the United Kingdom (UK), Chatterton states that social centers are nodes in an ever-expanding network in which people interested in alternative values and practices circulate (2010, p. 1213). In a rizhomatic or network society's understanding of social movements, the Occupy movement and its offshoots are yet other nodes that have created possibilities to an evergrowing crowd in search of other ways of being, governing and living.

Occupy as an open space had its share of problems and issues. There were constant tensions arising within the spaces around issues of unity and inclusion, which sometimes helped move issues forward, but also often resulted in failures to deal with them. One of the occupiers said: "The Occupy spaces were messy, impure and needed constant (re)working and (re)adjusting" (Member of the Fem Direct Action Working Group, personal communication, November 16th, 2012). Moreover, Occupy provided space where identities were incomplete, complex and multiple, such as with self-managed social centers (Chatterton, 2010).

Nonetheless, despite these tensions Occupy was seen as a new paradigm. As one occupier stated: "It's crazy to be in a paradigm where you have more of a right to call out patriarchy and oppression" (Member of the Fem Direct Action Working Group, personal 
communication, November 16th, 2012). The politics of opening and becoming in terms of individual and collective identities was at the heart of Occupy. The Occupy experiment goes hand in hand with what Gibson-Graham (2006) has argued: that it is in such spaces (anti-capitalist spaces) that new identities and relations can emerge.

\section{Opening Spaces, Opening Minds}

In a society that did not tolerate radical ideas such as direct action and squatting, Occupy was nonetheless succeeding in using such protest tactics on a day-to-day basis and with much approval from the general public. One of their strategies was in the ways in which they framed their message. Never did OWS used the term squatting to describe itself or even its protest tactic. This helped to create an imaginary where direct action, squatting and radical politics were not only used daily, attracted a growing number of people, but also started to permeate the imagination of more and more people.

One of the offshoots of Occupy Wall Street was the Occupy our Homes campaign, a campaign born on December 6th 2011. The campaign has been recognised as one of the most successful campaign that came out of the Occupy movement and which succeeded in building a lot of support from a wide range of people around issues of the right to housing and the right to use direct action to reclaim emptied or foreclosed homes. The fact that a bank, could technically own property that was emptied while someone had just lost their home, was incongruent to a wide American audience in a context of widespread foreclosures. The campaign, pointed to some systemic problems in ways that resonated with many Americans following the eviction of many Occupy sites. In addition to being a systemic problem that many could agree and get behind in a context of the economic crisis, the campaign was proposing practical solutions to a problem that was affecting a great number of, particularly black and Latino, people.

In framing the discourse about Occupy our Homes, activists were very careful in never calling it squatting because, as one occupier stated: "outside of anarchism in the USA, squatting is not an accepted term" (Member of Occupy our Homes, personal communication, November 14, 2011). Rather, they wanted to create acceptance of a tactic that Americans started to be familiar with. "We made squatting cool again in the USA, without calling it squatting" (Members of the Transworld Order Affinity Group, personal communication, November 21, 2011). Spaniards taking part in the M15M were also very careful in the use of the term squatting (okupacion). In fact, they did not use the term at all and rather relied on terms such the recuperation of public space or liberation of space because of the negative connotation associated with squatting.

Being careful with messaging and semantics turned out to be successful. Staying away from the use of the term squatting and calling it instead "Occupy our Homes" helped create a sense of identity around such housing movement using a popular brand name recognisable and favorable to many. All and all, it helped legitimise a tactic that in another context might have been very difficult to accept.

Following the eviction of the Occupy sites, what happened in the USA and what is different from the M15M is that instead of an explosion of new squats as in Spain (See Martinez \& Garcia, 2011), the USA movement saw a process of defending private proprieties from being foreclosed. The movements' convergence that happened in Spain between the squatters and the Occupy camps manifested itself differently in the USA. Post-eviction, many activists who had participated in Occupy sites and the 
public in general, who did not necessarily identified as activists, converged in resisting foreclosures in their communities. Many of the people who pioneered the Occupy our Homes campaign had previous ties to both the Occupy movement and the housing rights movement (Member of Occupy our Homes, personal communication, November 14, 2011). They used the momentum and branding created by Occupy to spur on a vibrant housing rights campaign in response to the foreclosures.

In an attempt to create new possibilities, it seems as though semantics were key for being able to dream without a set of pre-determined assumptions associated with a term such as squatting. It was also about creating a collective action frame that would resonate in people's imagination and help develop a sense of belonging behind a particular repertoire of actions. In talking about the values within self-managed social centers in the UK, Chatterton $(2010$, p. 1211) highlights that it is about what the collective imagination can get a way with; it is the collective imagination that helps shape the direction of the participants rather than the rules of engagement as prescribed by local states, urban life and society.

In the USA, as it has been highlighted, the situation was somewhat similar to Spain. With some exceptions, very few references were made to squatting or to the creation of self-managed social centers when talking and understanding the Occupy movement. Such exceptions are reflected in the failed attempt by Occupy Oakland (OO) to reclaim an unused Convention Center in order to give it stability in creating an occupied social center (Jourdan \& Martinez, 2012). There was also Occupy Seattle, which for a few weeks took over a vacant property to house occupiers and continue running Occupy activities as the winter was settling in (Valdes, 2011). These two examples, which explicitly used the term squatting were supported by very few people, and largely demonised for both their process and end goals. Such lack of support might be explained by the fact that the discourse on squatting in the USA is directly linked to the trespassing of the paramount private property principle. In other words, squatting is conceived and understood in very pejorative terms and has very little legitimacy in the USA outside of certain circles.

\section{Conclusion}

Throughout this article, it has been demonstrated that the protest tactic to occupy parks and squares have succeeded in opening up a specific repertoire of actions to attempt to resist unbridled capitalism in the USA. Reclaiming the city through longterm 'occupation' of spaces, particularly in key locations such as financial districts, has become somewhat of a new dimension or protest tactic of social movements. From North Africa, to the Middle East, to Europe to North America and back, all these movements, thanks in part to the power of information and communications technologies have inspired, influenced and shared tactics and strategies with one another. Like many other movements, Occupy has attempted to create autonomous spaces, an experiment as free as possible from capitalist values, relations and beliefs; Space from which unorthodox ideas could emerge. Such a space has also helped create and popularised new language, ideas and parameters.

This article has attempted to demonstrate the proximity between the ethos and project of self-managed social centers and the occupy movement. Through an examination of the similarities between these two phenomena one feature has come out strongly: the importance of territorially grounded projects where politics happens in the 
place where participants live. The devastation caused by casino-capitalism has triggered this imperative to reach out to one's own community and respond to local issues (such as housing) while anchoring ones project in a global understanding of inequalities.

Moreover, the creation of autonomous spaces via the protest tactic of the occupation of parks and squares throughout the USA has allowed for the emergence of radical autonomous projects that have helped open minds to alternatives. In fact, it is somewhat thanks to the Occupy movement that a large number of people have accepted the "occupation" or "liberation" of emptied or foreclosed homes as a legitimate repertoire of resistance in the present economic crisis. It also helped movements to converge and use each other's tactics. Radical politics through direct actions have entered the imaginaries of a growing number of the population in the USA and is now somewhat of a fixture of such movements of resistance.

\section{References}

Adbuster.(2011,July13).\#OCCUPYWALLSTREET: A shift in revolutionary tactics. Adbuster. Retrieved from http://www.adbusters.org/blogs/ adbusters-blog/occupywallstreet.html

Benford, R. D., \& Snow, D. A. (2000). Framing Processes and Social Movements: An Overview and Assessment. Annual Review of Sociology, 26, 611-639.

Burns, R. (2012, April 12). No Vacancies: Squatters Move In. In These Times. Retrieved from http://www.inthesetimes. com/article/13037/no_vacancies_ squatters_move_in /

Campbell, E. R. A. (2011). A critique of the Occupy movement from a black Occupier. The Black Scholar, 41, 42-51.

Castells, M. (2012). Networks of Outrage and Hope: Social Movements in the Internet Age. New York, NY: Polity.

Chatterton, P., Hodkinson S., \& Pickerill J. (2010). Beyond Scholar Activism: Making Strategic Interventions Inside and Outside the Neoliberal University. ACME: An International E-Journal for Critical Geographies, 9, 245-275.

Chatterton, P. (2010). So What Does It Mean to be Anti-capitalist? Conversations with Activists from Urban Social Centres. Urban Studies, 47, 1205-1224.

Chatterton, P. (2008). What's this place?. Red Pepper Magazine, August/September, 5153.

Chatterton, P., \& Hodkinson, S. (2007). Why we need social centres in the struggle against capitalism. In The Trapese Collective (Ed.), Do it yourself : a handbook for changing our world (pp. 201-215). London: Pluto Press.

Chatterton, P. (2002). Squatting is still legal, necessary and free: A brief intervention in the corporate city, Antipode, 34,1-7.

Clifford, J. (1986). Introduction: Partial truths. In J. Clifford \& G. Marcus (Eds.), Writing culture: The poetics and politics of ethnography (pp. 1-26). Berkeley: University of California Press.

Comrades from Cairo. (2011, October 24). Retrieved from https://occupyca. wordpress.com/2011/10/25/letter-fromcairo.

Noor, J. (2011, June 24). Welcome to Bloombergville: New York Activists Fight Budget Cuts By Camping in Front of City Hall. Democracy Now. Retrieved from http:/www.democracynow. org/blog/2011/6/24/welcome_to_ bloombergville_new_york_activists_fight_ budget_cuts_by_camping_in_front_of_ city_hall

Dyck, I. (2005). Feminist geography, the 'everyday', and local-global relations: hidden spaces of place-making, Suzanne Mackenzie Memorial Lecture, The Canadian Geographer / Le Geographe canadien, 49, 233-243.

Katsiaficas, G. (2006). The Subversion of Politics: European Autonomous Social Movements and the Decolonization of Everyday Life. Oakland, CA: AK Press.

Fuster Morell, M. (2012): The Free Culture and 15M Movements in Spain: Composition, Social Networks and Synergies. Social Movement Studies: Journal of Social, 
Cultural and Political Protest, 11, 386392.

Goldstein, K. (2012, November 4) Is Occupy Wall Street Outperforming the Red Cross in Hurricane Relief? Slate. Retrieved from http:// www.slate.com/blogs/the_slatest/2012/11/04/ occupy_sandy_hurricane_relief_being_led_ by_occupy_wall_street.html

Gibson-Graham, J.K. (2006). A Postcapitalist Politics. Minneapolis, MN : University of Minnesota Press.

Hakim, B. (1991). T.A.Z.: The Temporary Autonomous Zone, Ontological Anarchy, Poetic Terrorism. Brooklyn, NY: Autonomedia.

Hardt, M., \& Negri, A. (2009). Commonwealth. Cambridge, MA: Belknap Press.

Harvey, D. (2012). Rebel Cities: From the Right to the City to the Urban Revolution. Brooklyn. NY: Verso Press.

Harvey, D. (2008). The Right to the City. New Left Review, 53, 23-40.

Harvey, D. (2001). Spaces of Capital: Towards a Critical Geography. New York, NY: Routledge.

Hodkinson, S., \& Chatterton, P. (2006). Autonomy in the City? Initial reflections on the social centres movement in the UK, City, 10, 305-315.

Jourdan, B., \& Martinez, B. (2012, February $2)$. The Battle of Oakland. Retrieved from http://occupiedmedia.us/2012/02/thebattle-of-oakland/

Juris, J. (2008). Networking Futures: The Movements against Corporate Globalization. Durham, NC: Duke University Press.

Juris, J., Ronayne, M., Shokooh-Valle, F., \& Wengronowitz, R. (2012). Negotiating power and difference within the $99 \%$. Social Movement Studies, 11, 434-440.

Martinez, M. L. (2012). The Squatters' Movement in Europe: A Durable Struggle for Social Autonomy in Urban Politics, Antipode, 00, 1-22.

Martinez, M. L. (2007). The squatters' movement: Urban counter-culture and alter-globalisation dynamics. South European Society and Politics, 12, 379398.

Martinez, M. L. (2006). Countercultural Squatters in Spain. Casa Zine, 3, 8-15.
Martinez, M.L, \& Garcia, A. (2011). The Occupation of Squares and the Squatting of Buildings: Lessons From the Convergence of Two Social Movements. Retrieved from http:/www.miguelangelmartinez.net/IMG/ pdf/articulo_Bilbao_v4_book_doc.pdf

Maxigas. (2012). Hacklabs and hackerspaces - tracing two genealogies. Journal of Peer Production, 2, 1-10. Retrieved from http://peerproduction.net/issues/issue-2/ peer-reviewed-papers/hacklabs-andhackerspaces/

Montagna, N. (2006). The de-commodification of urban space and the occupied social centres in Italy. City: analysis of urban trends, culture, theory, policy, action, 10, 295-304.

Mudu, P. (2004). Resisting and Challenging Neoliberalism: The Development of Italian Social Centres. Antipode, 36, 917-41.

McKenzie, W. (2011). The Beach Beneath the Street. Brooklyn, NY: Verso Press.

Piazza, G. (2011). Which models of democracy? Internal and external decision-making processes of Italian Social Centres in a comparative study. Center of Studies on Politics and Society-WP Series, 1, 3-54.

Pickerill, J. \& Krinsky, J. (2012): Why Does Occupy Matter?, Social Movement Studies: Journal of Social, Cultural and Political Protest, 11, 279-287.

Pickerill, J., \& Chatterton, P. (2006). Notes towards autonomous geographies: creation, resistance and self-management as survival tactics. Progress in Human Geography, 30, 730-746.

Pickvance, C. (2003). From urban social movements to urban movements. International Journal of Urban and Regional Research, 27,102-109.

Pleyers, G. (2010). Alter-Globalization: Becoming Actors in the Global Age. Cambridge, MA: Polity Press.

Pruijt, H. (2013). The logic of urban squatting. International Journal of Urban and Regional Research, 37.1,19-45.

Pruijt, H. (2007). Urban movements. In G. Ritzer, (Ed.)

The Blackwell Encyclopedia of Sociology (pp. 5115-5119). Oxford: Blackwell

Pruijt, H. (2003). Is the institutionalisation of urban movements inevitable? A comparison of the opportunities for sustained squatting 
in New York City and Amsterdam. International Journal of Urban and Regional Research, 27,133-157.

Pusey, A., \& Chatterton, P. (2008). Hotspots: Social Centres, New Internationalist. November, 6-7. Retrieved from http:// www.paulchatterton.com/wp-content/ uploads/2009/05/hotspots_ni_08.pdf

Ruggiero, V. (2000). New Social Movement and the "centri sociali" in Milan. Sociological Review, 48, 167-85.

Squatting Europe Kollective (Ed). (2013). Squatting in Europe: Radical Spaces, Urban Struggles, Brooklyn, NY: Autonomedia.

Special Holiday Event: An Insider's View of Occupy Wall Street, Retrieved from You Tube https://www.youtube.com/ watch?v=W-cW7GC23hw

Strange, S. (1997). Casino capitalism. Manchester, UK: Manchester University Press.

Valdes, M. (2011, November 29). Occupy's new tacticontheWestCoast:Squatting. TheSeattle Times. Retrieved from http://seattletimes. com/html/localnews/2016886287. apwaoccupyseattlesquatting.html 